\title{
Biochemical and Histological Change during Chilled Storage in Farmed Raised and Wild Indian Butter Catfish (Ompok bimaculatus Bloch, 1794)
}

\author{
Jag Pal $^{1}$, A.U. Muzaddadi ${ }^{2}$ and Hemant Hari Tripathi ${ }^{2}$ \\ ${ }^{I}$ Department of Fish Processing Technology, KVAFSU, College of Fisheries, \\ Mangalore, Karnataka, India \\ ${ }^{2}$ ICAR-Central Institute of Post-Harvest Engineering and Technology (CIPHET), \\ Ludhiana, India
}

*Corresponding author

\section{Keywords}

Ice storage,

Microbiological,

Histological and

Wild Pabda

\section{Article Info}

Accepted:

12 February 2019

Available Online:

10 March 2019

\section{A B S T R A C T}

The shelf life of farm raised and wild caught Indian butter catfish during ice storage were studied in terms of biochemical, microbiological and histological. The farmed and wild pabda were stored in standard ice-boxes with flake ice (1:1). The samplings were performed at 2 days interval. During storage period, the moisture, ash, protein and lipid contents of all the treatments changed significantly $(\mathrm{p}<0.05)$ with the days of storage and also with specific treatments. The $\mathrm{pH}$ value increased significantly $(\mathrm{p}<0.05)$ in all treatments with a final value was less than 7 . Free fatty acids (FFA), peroxide value (PV) and thiobarbituric acid (TBA) increased significantly $(\mathrm{p}<0.05)$ after $6^{\text {th }}$ day of storage. The Total Volatile Base Nitrogen (TVB-N) and alpha amino nitrogen (AAN) compounds also increased significantly $(\mathrm{p}<0.05)$ after $4^{\text {th }}$ day of storage in all treatments, however the TVB-N content was within the acceptable level till the end of storage period of 8 days. The Total plate count (TPC) and total psychrophilic count remained below the limit (7 log cfu g-1) in Wiled whole pabda (WWP) and Farmed whole pabda (FWP) after $6^{\text {th }}$ days of storage which exceeded the limit on $8^{\text {th }}$ days of storage in whole sample, whereas dressed sample Wild dressed pabda (WDP) and Wild whole pabda (WWP) still it remained acceptable for dressed samples. The sensory score of dressed pabda was marginally acceptable up to the 6 days of storage whole pabda was acceptable up to 4 days. The histological changes in fresh pabda muscles did not show any microstructural changes, whereas deformations of muscle fibres and optically empty areas were found in iced pabda at the end of $8^{\text {th }}$ days of storage. Thus the present study advocates preservation of pabda by minimum dressing and then icing in ice-box which can extend the shelf life for at least 6 days whereas the whole iced pabda will remain acceptable for 3 days only.

\section{Introduction}

Indian butter catfish (Ompok bimaculatus, Bloch, 1794) comes under the order
Siluriformes and family Siluridae. The specific name bimaculatus implies the two spots on anterior sides. In global market this species is known as the two spot glass catfish 
and as pabda in Tripura, India. Pabda has a high demand in the market for its excellent taste and flavor, pin-boneless muscle and traditional delicacies associated with the fish. The total world fish production is 170.9 million tones 2016 (FAO, 2018) and India has an important role in global fish production as the second largest fish producer with 11.46 million tones. However, it is a well known fact that a huge amount of fish are lost due to meat quality deterioration, mainly because of the lack of science-based information on postharvest fish handling and the forms of preservation that might guarantee the high quality of the product. This has been a major impediment to market development. Thus, the scientific studies on fish preservation and shelf life extension are still essentially required especially in the developing countries like India. The Biochemical and microbiological changes in fish tissue after harvest determine the quality of fish. These changes mainly depend on factors that affect substrate and metabolite concentration in living animal tissue, activity of endogenous enzymes, and natural and post-catch microbiological contamination (Fatima et al., 1985, Sikorski et al., 1994). The simplest method of control of spoilage in fish is by icing. In tropical condition the iced fish will remain in good condition up 10-12 days but depend on several factors. Lokuruka et al., (2012) reported that the, effect of gutting on sensory, biochemical and microbiological properties of nile perch (Lates niloticus) and nile tilapia (Oreochromis niloticus) stored in iced gutting increased shelf life by 4 days. The effect of gutting showed to maintain sensory acceptance and to reduce volatile amine content in lean fish (Botta et al., 1982), while no effect was observed on quality for fatty fish (Karaçam and Boran, 1996). Binsi et al., 2013, studied the microbiological and shelf life characteristics of eviscerated and vacuum packed Ompok pabda during chill storage and they reported the extension of 4 days in storage life. Menon, and Nair (1988) studied the histological changes in fresh water fish muscle stored in chilled condition and reported that the, Structural changes occurring in the skeletal muscle of Labeo calbasu, a major carp, during ice storage (0-1 degree C) were studied histologically. Fresh muscle tissue showed closely packed uniform bundles of myofibrils, with well-defined striations and clearly visible nuclei. On storage, there was progressive disruption in this compact picture, with deterioration of the organization of the structure characterized by fissures and breaks in the fibres leading to dislocation and mutilation of myofibrils. Such changes were in line with concomitant softening in the texture of the muscle observed in the stored fish. In view of this, the present study was undertaken to determine the biochemical, microbiological, sensory and histological characteristics of Ompok bimacultus under iced storage.

\section{Materials and Methods}

\section{Sample collection and storage technique}

The wild pabda were collected from the Gomti River Tripura and farmed pabda from College of fisheries Tripura India. After collection of both samples were immediately stored in ice box by mixing ice 1:1 ratio. Sample was brought to the Laboratory of department of Fish Processing Technology College of fisheries Tripura. Fish were washed properly with water to remove the slimes and blood clots from the skin. After washing the fish were stored as whole and dressed farm. The treatment was labeled as wild dressed pabda (WDP), wild whole pabda (WWP), farmed dressed pabda (FDP) and farmed whole pabda (FWP) respectively. All the treatments were stored in 4 ice boxes in alternating layers of ice and fish using flake ice in the ratio of 1:1. The boxes were kept at the ambient temperature for further storage study. 
Sampling was performed at 2 days interval by estimation of biochemical, microbiological and Sensory characteristics for all the treatments.

\section{Storage life study}

\section{Biochemical analysis}

The values of the proximate composition sample were determined by the standard method of AOAC (2000). Moisture content was estimated by direct heating method in oven. Crude protein was measured by the Kjeldahl's method using a digestion unit, a distillation unit and a titration unit. Lipid content was determined by Soxhlet Extraction apparatus. Total volatile base nitrogen (TVB$\mathrm{N}$, mgN $100 \mathrm{~g}-1$ ) was determined by the Conway micro diffusion method described by Beatty and Gibbon (1937).

The peroxide value (PV) of was estimated by using iodometric titration method as described by Jacobs (1958). The free fatty acid (FFA) content in sample was determined by the method of Dyer and Morton (1956) and expressed as \% of FFA oleic acid. Free $\alpha$ amino nitrogen was determined by Pope and Stevens, (1939) and Thiobarbituric acid (TBA) number was determined by the Tarladgis et al., (1960) all the sampled were performed in triplicate.

\section{Bacteriological analysis}

In order to assess the microbial load, $10 \mathrm{~g}$ of each treatment sample was aseptically collected and macerated with $90 \mathrm{ml}$ sterile saline. After making serial dilution in the same diluents, spared plating was done on nutrient agar plates. Total plate count was recorded after $24 \mathrm{~h}$ of incubation at $37{ }^{\circ} \mathrm{C}$ and was expressed as $\log _{10} \mathrm{cfu}$ (colony forming units)/g.

\section{Muscle/tissue analysis}

The tissue processing, embedding and section preparation were carried out by following the method given by Menon and Nair (1987), using automated tissue processor and (Thermo scientific-Shadon, citadel 2000, USA), automated tissue embedder (Shadon Histocentor 3, processi USA) and rotatory microtome (Leica RM2245, Germany).

\section{Statistical analysis}

The data obtained from microbiological and biochemical analysis was analyzed by using Statistical Package for Social Sciences (SPSS, version 21.0 for Windows). Analysis of variance (One way- ANOVA) was performed in order to compare the changes during sampling period. The level of significance of differences was defined at $\mathrm{p}<0.05$.

\section{Results and Discussion}

The moisture content significantly increased with the increased in storage time. In case of wild pabda the initial moisture contents was $75.43 \%$ which increased up to $79.63 \%$ and $80.02 \%$ in WDP and WWP respectively (Table 1 and 3) at the end 8 days storage. The same increasing trends of moisture contents were also recorded in wild pabda. The moisture increment was found little higher in the dressed pabda. This may be because of exposure of more flesh to ice melt water, since dressing increased surface area of fish. Chakrabarti (2002) recorded higher moisture content with no significant changes during storage in several marine fishes. The ash contents in all samples decreased significantly $(p<0.05)$ throughout the period of storage. The initial ash content in wild fish was $0.98 \%$ which decreased to $0.58 \%$ and $0.53 \%$ in WWP and WDP respectively (Table 1 and 3). Similar decrease was also observed in samples of FWP and FDP. The decreasing trend was 
observed in the all samples, which may be attributed to the leaching of mineral in the icemelt-water. However, the loss of mineral was found to be more in WDP and FDP than the WWP and FWP. This apparently is because of exposure of more flesh surfaces in the ice melt water which enhanced the leaching mineral contents from the fish. During the storage period protein content significantly $(p<0.05)$ decreased in both sample WWP and WDP during the period of study. The initial protein value of 16.69 decreased to $14.32 \%$ and $14.46 \%$ in WWP and WDP (Table 1 and 3). Whereas, the initial protein content (16.54\%) decreased to $14.45 \%$ and 14.52 respectively in FWP and FDP after 8 days.

The protein content decreased significantly $(\mathrm{p}<0.05)$ throughout the study periods in all the samples (Table 1 and 3). The protein content decrease was comparatively more in whole fishes, i.e., WWP and FWP, It may be due to the presence of gut contents which is favourable for bacterial growth and enzymatic action and this might have resulted in more protein degradation by bacteria in the whole fish. The decrease in protein may be due to leaching of soluble nitrogenous compounds in ice melt water. The present finding also in support with finding of Kolodziejska et al., (1987) who have observed that low temperature, the rate of denaturation and autolysis of fish protein was markable. The autolysis helps the bacteria to invade the tissue fast, the free aminoacids and water soluble protein content of tissue serve as an excellent source for their growth and as a resultant the quantity of protein is decreased.

The lipid contents in all the samples significantly $(\mathrm{p}<0.05 \%)$ decreased during the period of storage with respect to sampling. It was observed that the initial lipid content $(6.66 \%)$ decreased to $4.41 \%$ and $4.37 \%$ in WWP and WDP respectively (Table 1 and 3) after 8 days of storage. On the other hand same was also observed in farmed pabda. The current instigation also support to the finding of (Nazeer et al., 2009) and Gopakumar 1997). The major factor responsible for the deterioration of fish is oxidation of lipid (Roopma et al., 2012). The lipid content the fat content varies with sex, age and season (Gopakumar, 1997).

The AAN content increased significantly ( $\mathrm{p}$ $<0.05$ ) in both sample of fish as a whole and as dressed (Table 2 and 4). The AAN content in dressed fish was found to be less in comparison to that of fish which were stored as the whole. This may be because of low enzymatic (autolytic) and microbial activity due to the absence of gut content. The removal of gut resulted in removal of gut enzymes and bacteria which reduced the enzymatic and bacterial activity to a great extent, and thus, could be responsible for relatively more shelf life of pabda which was stored as the dressed.

In the present study, the TVB-N content significantly changed $(\mathrm{p}<0.05)$ during the storage period both in farmed (FDP and FWP) and wild padda (WDP and FDP) (Table 2 and 4). However, the TVB-N content did not exceed above acceptable limit, i.e. $35 \mathrm{mg}$ $\mathrm{N} / 100 \mathrm{~g}$ (FAO, 1986). Lower TVB-N value in dressed fish may be due to the removal of gut along with gut enzymes and bacteria which may be responsible for lower autolytic and bacterial activity, which could have resulted in longer shelf life of dressed pabda than that of whole pabda. The increasing in TVB-N value was comparable with the increasing TVBN value as reported by Ozyurt et al., (2009) for chilled storage of red mullet (Mullus barbatus). This increase could be attributed to the production of ammonia and other volatile amines in the muscle during storage (Mazorra et al., 2000). Present findings are in agreement with the Lokuruka et al., (2012) who found increased level of TVBN in the unguted and gutted experimental tilapia with storage time 
in ice. In the present study the TVB-N value did not show any significant difference $(p>0.05)$ after $0,2^{\text {nd }}$ and $4^{\text {th }}$ days of storage in both conditions, whether whole or as dressed with respect to treatments. But after 6 days of storage, the TVB-N of WWP showed significant increase $(p<0.05)$ compared to WDP and TVB-N of FWP also showed significant increase $(\mathrm{p}<0.05)$ compared to WDP on the 8th day of storage.

The Primary oxidation products of the fish sample were measured by the peroxide value and are expressed as meq $\mathrm{O} 2 / \mathrm{kg}$ of fat. In the present study it was observed that the PV increased significantly $(\mathrm{p}<0.05)$ both in whole and dressed pabda. The PV value was observed higher in the WWP and FWP than in the FDP and WDP. Similar results were also reported by Viji (2014) in chilled steaks of Silver carp where the PV value increased with increased in storage time. During the lipid oxidation Hydroperoxide formed as primary oxidation products at higher levels might undergo the decomposition into secondary oxidation products. Lipid oxidation in fifo depends on numerous factors such as species, storage temperature, fat composition, and it produces a number of substances, some of which have unpleasant flavours and odours. Some may also contribute to texture changes, by forming covalent bonds with muscular proteins (Huss, 1995).

The Free fatty acid is the resultant products of hydrolytic rancidity of lipids which is expressed as \% of oleic acid. The FFA is a result of enzymatic decomposition of lipid during storage leading to lipid hydrolysis (Tokur et al., 2006). The, the initial FFA (\% oleic acid) increased significantly $(\mathrm{p}<0.05)$ throughout the period of storage, whether fish was preserved whole or dressed. Free fatty acids got generated during storage mostly which may be due to the activity of lipases present both in tissue and also of microbial origin (Koizumi et al., 1990). The TBA values represent the degree of the rancidity in the product and the value 3-4 indicates quality lose (Karacam and Boran, 1996). The TBA increased significantly $(\mathrm{p}<0.05)$ in all the treatments during storage period of 8 days. In case of WWP and WDP, the initial TBA value 0.44 increased up to 1.82 and 1.72 in WWP and WDP respectively during the storage periods. Similarly in farmed pabda, the TBA value was higher in WDP and FDP (Table 2 and 4).

The $\mathrm{pH}$ value Increased significantly $(\mathrm{p}<0.05)$ in the farmed and wild pabda in both dressed and whole condition during storage. During later postmortem stages, there is a $\mathrm{pH}$ increase, due to decomposition of nitrogenated compounds, caused primarily by microbial activity (Hernandez et al., 2009). The intensity of this $\mathrm{pH}$ change depends mainly on the storage temperature, with $\mathrm{pH}$ values above 7.1 being indicative of decomposition. The total plate counts (TPC) of all samples changed significantly $(\mathrm{p}<0.05)$ during the storage period of 8 days (Table 5). The TPC of whole fish was observed to be higher than that of dressed fish. This may be due to the inclusion of gut contents in fish, because the gut content harbors high the bacterial load which may percolate to the muscle during storage. Chytiri et al., (2004) also reported that bacterial count of whole ungutted trouts were always lower than those obtained for filleted trout sample and in their study mesophillic count for filleted and ungutted fish exceeded the acceptable limit ( $7 \log \mathrm{cfu} \mathrm{cm}^{-2}$ ) after 10 and 18 days of ice storage, respectively. The ICMSF (1986) established an aerobic mesophilic count limit of $7 \log \mathrm{cfu} \mathrm{g}^{-1}$ for fish that is fit for human consumption. In the present study too, TPC in whole treatments was exceeding $7 \log \mathrm{cfu} \mathrm{g}^{-1}$ during the storage period, however in dressed pabda the TPC was near $7 \log \mathrm{cfu} \mathrm{g}^{-1}$. 
Table.1 Changes in proximate composition during ice storage of WWP and WDP [Values are Mean with the S.E. in parentheses, n=3]

\begin{tabular}{|c|c|c|c|c|c|c|c|c|c|c|}
\hline \multirow[t]{2}{*}{ Parameters } & \multicolumn{2}{|c|}{0 day } & \multicolumn{2}{|c|}{$2^{\text {nd }}$ day } & \multicolumn{2}{|c|}{$4^{\text {th }}$ day } & \multicolumn{2}{|c|}{$6^{\text {th }}$ day } & \multicolumn{2}{|c|}{$8^{\text {th }}$ day } \\
\hline & WWP & WDP & WWP & WDP & WWP & WDP & WWP & WDP & WWP & WDP \\
\hline Moisture*(\%) & $\begin{array}{c}75.43^{\mathrm{aA}} \\
(0.23)\end{array}$ & $\begin{array}{c}75.43^{\mathrm{aA}} \\
(0.23)\end{array}$ & $76.55^{\mathrm{bA}}(0.82)$ & $76.67^{\mathrm{bA}}(0.14)$ & $\begin{array}{c}77.53^{\mathrm{cA}} \\
(0.93)\end{array}$ & $\begin{array}{c}77.92^{\mathrm{cA}} \\
(0.15)\end{array}$ & $\begin{array}{c}78.21^{\mathrm{dA}} \\
(0.86)\end{array}$ & $\begin{array}{c}79.41^{\mathrm{dA}} \\
(0.41)\end{array}$ & $\begin{array}{c}79.63^{\mathrm{eA}} \\
(0.56)\end{array}$ & $\begin{array}{c}80.07^{\mathrm{eA}} \\
(0.18)\end{array}$ \\
\hline $\operatorname{Ash}^{*}(\%)$ & $\begin{array}{l}0.98^{\mathrm{aA}} \\
(0.04)\end{array}$ & $\begin{array}{l}0.98^{\mathrm{aA}} \\
(0.04)\end{array}$ & $0.87^{\mathrm{dA}}(0.03)$ & $0.85^{\mathrm{bA}}(0.02)$ & $\begin{array}{l}0.76^{\mathrm{cA}} \\
(0.05)\end{array}$ & $\begin{array}{l}0.69^{\mathrm{cA}} \\
(0.03)\end{array}$ & $\begin{array}{l}0.63^{\mathrm{bA}} \\
(0.05)\end{array}$ & $\begin{array}{l}0.55^{\mathrm{dA}} \\
(0.02)\end{array}$ & $\begin{array}{c}0.58^{\mathrm{aAB}} \\
(0.04)\end{array}$ & $\begin{array}{l}0.53^{\mathrm{eA}} \\
(0.02)\end{array}$ \\
\hline Protein* $(\%)$ & $\begin{array}{c}16.69^{\mathrm{dA}} \\
(0.20)\end{array}$ & $\begin{array}{c}16.69^{\mathrm{dA}} \\
(0.20)\end{array}$ & $15.66^{\mathrm{cA}}(0.13)$ & $15.77^{\mathrm{cA}}(0.14)$ & $\begin{array}{c}15.24^{\mathrm{bA}} \\
(0.09)\end{array}$ & $\begin{array}{c}15.43 \mathrm{a}^{\mathrm{bA}} \\
(0.10)\end{array}$ & $\begin{array}{c}14.63^{\mathrm{aA}} \\
(0.15)\end{array}$ & $\begin{array}{c}15.07^{\mathrm{bB}} \\
(0.10)\end{array}$ & $\begin{array}{c}14.32^{\mathrm{a} A} \\
(0.16)\end{array}$ & $\begin{array}{c}14.46^{\mathrm{aA}} \\
(0.12)\end{array}$ \\
\hline Fat* $(\%)$ & $\begin{array}{l}6.66^{\mathrm{dA}} \\
(0.17)\end{array}$ & $\begin{array}{l}6.66^{\mathrm{aA}} \\
(0.22)\end{array}$ & $\begin{array}{c}5.97^{\mathrm{aAB}} \\
(0.19)\end{array}$ & $\begin{array}{l}6.22^{\mathrm{cA}} \\
(0.16)\end{array}$ & $\begin{array}{l}5.40^{\mathrm{cA}} \\
(0.16)\end{array}$ & $\begin{array}{l}5.46^{\mathrm{bA}} \\
(0.17)\end{array}$ & $\begin{array}{c}4.96 b^{A} \\
(0.14)\end{array}$ & $\begin{array}{l}4.88^{\mathrm{bA}} \\
(0.24)\end{array}$ & $\begin{array}{c}4.37^{\mathrm{aA}} \\
(0.15)\end{array}$ & $\begin{array}{l}4.41^{\mathrm{aA}} \\
(0.15)\end{array}$ \\
\hline
\end{tabular}

Mean values bearing different superscripts in small letters $(a, b, c$ etc) in the rows are significantly different $(p<0.05)$ with respect to sampling and the

values with different superscripts in Caps $(\mathrm{A}, \mathrm{B}, \mathrm{C}$ etc) in the columns are significantly different $(\mathrm{p}<0.05)$ with respect to the treatments

Table.2 Changes of biochemical parameters during ice storage of WWP and WDP [Values are Mean with the S.E. in parentheses, $\mathrm{n}=3$ ]

\begin{tabular}{|c|c|c|c|c|c|c|c|c|c|c|}
\hline \multirow[t]{2}{*}{ Parameters } & \multicolumn{2}{|c|}{0 day } & \multicolumn{2}{|c|}{$2^{\text {nd }}$ day } & \multicolumn{2}{|c|}{$4^{\text {th }}$ day } & \multicolumn{2}{|c|}{$6^{\text {th }}$ day } & \multicolumn{2}{|c|}{$8^{\text {th }}$ day } \\
\hline & WWP & WDP & WWP & WDP & WWP & WDP & WWP & WDP & WWP & WDP \\
\hline $\mathbf{p H}^{*}$ & $\begin{array}{l}6.38^{\mathrm{aA}} \\
(0.05)\end{array}$ & $6.38^{\mathrm{aA}}(0.04)$ & $\begin{array}{c}6.57^{\mathrm{abA}} \\
(0.02)\end{array}$ & $\begin{array}{c}6.48^{\mathrm{aAB}} \\
(0.04)\end{array}$ & $\begin{array}{l}6.48^{\mathrm{bA}} \\
(0.02)\end{array}$ & $\begin{array}{l}6.68^{\mathrm{bB}} \\
(0.04)\end{array}$ & $\begin{array}{l}6.72^{\mathrm{cB}} \\
(0.05)\end{array}$ & $\begin{array}{c}6.76 b^{\mathrm{cB}} \\
(0.03)\end{array}$ & $\begin{array}{l}6.80^{\mathrm{cA}} \\
(0.05)\end{array}$ & $\begin{array}{l}6.82^{\mathrm{cA}} \\
(0.03)\end{array}$ \\
\hline PV* (meq/kg fat) & $\begin{array}{c}11.45^{\mathrm{aA}} \\
(0.40)\end{array}$ & $11.45^{\mathrm{aA}}(0.29)$ & $\begin{array}{c}12.02^{\mathrm{aA}} \\
(0.21)\end{array}$ & $\begin{array}{c}11.99^{\mathrm{aA}} \\
(0.55)\end{array}$ & $\begin{array}{c}14.39^{\mathrm{bA}} \\
(0.14)\end{array}$ & $\begin{array}{c}14.85^{\mathrm{bA}} \\
(0.39)\end{array}$ & $\begin{array}{c}18.49^{\mathrm{cB}} \\
(0.29)\end{array}$ & $\begin{array}{c}16.74^{\mathrm{cA}} \\
(0.21)\end{array}$ & $\begin{array}{c}23.54^{\mathrm{dA}} \\
(0.68)\end{array}$ & $\begin{array}{c}21.97^{\mathrm{dA}} \\
(0.65)\end{array}$ \\
\hline TVB-N* (mg \%) & $\begin{array}{l}7.46^{\mathrm{aA}} \\
(0.78)\end{array}$ & $7.46^{\mathrm{aA}}(0.42)$ & $\begin{array}{c}12.60^{\mathrm{bA}} \\
(0.67)\end{array}$ & $\begin{array}{c}10.99^{\mathrm{bA}} \\
(0.91)\end{array}$ & $\begin{array}{c}15.43^{\mathrm{cA}} \\
(0.47)\end{array}$ & $\begin{array}{c}14.94^{\mathrm{cA}} \\
(0.90)\end{array}$ & $\begin{array}{c}23.74^{\mathrm{dB}} \\
(0.63)\end{array}$ & $\begin{array}{c}20.88^{\mathrm{dA}} \\
(0.82)\end{array}$ & $\begin{array}{c}26.47^{\mathrm{eAB}} \\
(0.63)\end{array}$ & $\begin{array}{c}24.54^{\mathrm{eA}} \\
(0.85)\end{array}$ \\
\hline $\mathbf{A A N}^{*}(\mathbf{m g} \%)$ & $\begin{array}{c}60.70^{\mathrm{aB}} \\
(0.78)\end{array}$ & $60.70^{\mathrm{aB}}(3.34)$ & $\begin{array}{c}70.47^{\mathrm{bB}} \\
(4.70)\end{array}$ & $\begin{array}{c}65.13^{\mathrm{aAA}} \\
(0.91)\end{array}$ & $\begin{array}{c}74.51^{\mathrm{bB}} \\
(3.97)\end{array}$ & $\begin{array}{c}72.05^{\mathrm{bAB}} \\
(0.90)\end{array}$ & $\begin{array}{c}84.67^{\mathrm{cB}} \\
(3.24)\end{array}$ & $\begin{array}{c}82.13^{\mathrm{cAB}} \\
(0.82)\end{array}$ & $\begin{array}{c}88.93^{\mathrm{cA}} \\
(4.52)\end{array}$ & $\begin{array}{c}88.89^{\mathrm{dA}} \\
(0.85)\end{array}$ \\
\hline FFA (\% oleic acid) & $\begin{array}{l}6.44^{\mathrm{aA}} \\
(1.54)\end{array}$ & $6.44^{\mathrm{aA}}(0.14)$ & $\begin{array}{c}8.46^{\mathrm{aaB}} \\
(0.44)\end{array}$ & $\begin{array}{l}7.88^{\mathrm{abB}} \\
(1.46)\end{array}$ & $\begin{array}{l}9.11^{\mathrm{bA}} \\
(0.40)\end{array}$ & $\begin{array}{c}8.75 b^{\mathrm{cA}} \\
(2.61)\end{array}$ & $\begin{array}{c}10.73^{\mathrm{bbA}} \\
(0.97)\end{array}$ & $\begin{array}{c}9.75^{\mathrm{cdA}} \\
(1.94)\end{array}$ & $\begin{array}{c}11.64^{\mathrm{cA}} \\
(1.29)\end{array}$ & $\begin{array}{c}10.70^{\mathrm{dA}} \\
(2.02)\end{array}$ \\
\hline $\begin{array}{l}\text { TBA*(mgmalonaldehyde } \\
\text { /kg }\end{array}$ & $\begin{array}{l}0.44^{\mathrm{aA}} \\
(0.25)\end{array}$ & $0.44^{\mathrm{aA}}(0.13)$ & $\begin{array}{l}0.87^{\mathrm{bA}} \\
(0.07)\end{array}$ & $\begin{array}{l}0.81^{\mathrm{bA}} \\
(0.19)\end{array}$ & $\begin{array}{l}1.03^{\mathrm{bcA}} \\
(0.03)\end{array}$ & $\begin{array}{l}0.92^{\mathrm{bA}} \\
(0.56)\end{array}$ & $\begin{array}{l}1.28^{\mathrm{cA}} \\
(0.03)\end{array}$ & $\begin{array}{l}1.20^{\mathrm{bA}} \\
(0.84)\end{array}$ & $\begin{array}{l}1.82^{\mathrm{dA}} \\
(0.06)\end{array}$ & $\begin{array}{l}1.70^{\mathrm{cB}} \\
(0.72)\end{array}$ \\
\hline
\end{tabular}

Mean values bearing different superscripts in small letters $(a, b$, c etc) in the rows are significantly different(p<0.05) with respect to sampling and the values with different superscripts in Caps $(\mathrm{A}, \mathrm{B}, \mathrm{C}$ etc) in the columns are significantly different $(\mathrm{p}<0.05)$ with respect to the treatments. 
Table.3 Changes of proximate composition during ice storage of and FWP and FDP [Values are Mean with the S.E. in parentheses, $\mathrm{n}=3$ ]

\begin{tabular}{|c|c|c|c|c|c|c|c|c|c|c|}
\hline \multirow[t]{2}{*}{ Parameters } & \multicolumn{2}{|c|}{0 day } & \multicolumn{2}{|c|}{$2^{\text {nd }}$ day } & \multicolumn{2}{|c|}{$4^{\text {th }}$ day } & \multicolumn{2}{|c|}{$6^{\text {th }}$ day } & \multicolumn{2}{|c|}{$8^{\text {th }}$ day } \\
\hline & FWP & FDP & FWP & FDP & FWP & FDP & FWP & FDP & FWP & FDP \\
\hline Moisture*(\%) & $\begin{array}{c}75.14^{\mathrm{aA}} \\
(0.13)\end{array}$ & $\begin{array}{c}75.13^{\mathrm{aA}} \\
(0.13)\end{array}$ & $\begin{array}{c}76.46^{\mathrm{bA}} \\
(0.27)\end{array}$ & $\begin{array}{c}75.98^{\mathrm{aA}} \\
(0.22)\end{array}$ & $\begin{array}{c}78.08^{\mathrm{cA}} \\
(0.31)\end{array}$ & $\begin{array}{c}77.27^{\mathrm{bA}} \\
(0.51)\end{array}$ & $\begin{array}{c}78.86^{\mathrm{dA}} \\
(0.29)\end{array}$ & $\begin{array}{c}79.10^{\mathrm{cA}} \\
(0.40)\end{array}$ & $\begin{array}{c}79.73^{\mathrm{eA}} \\
(0.19)\end{array}$ & $\begin{array}{c}80.04^{\mathrm{dA}} \\
(0.19)\end{array}$ \\
\hline $\operatorname{Ash}^{*}(\%)$ & $\begin{array}{l}1.06^{\mathrm{eA}} \\
(0.02)\end{array}$ & $\begin{array}{l}1.06^{\mathrm{dA}} \\
(0.02)\end{array}$ & $\begin{array}{l}0.95^{\mathrm{cB}} \\
(0.03)\end{array}$ & $\begin{array}{l}0.95^{\mathrm{dB}} \\
(0.02)\end{array}$ & $\begin{array}{c}0.83 b^{\mathrm{AB}} \\
(0.05)\end{array}$ & $\begin{array}{l}0.78^{\mathrm{cB}} \\
(0.03)\end{array}$ & $\begin{array}{l}0.74^{\mathrm{bB}} \\
(0.05)\end{array}$ & $\begin{array}{l}0.66^{\mathrm{bB}} \\
(0.03)\end{array}$ & $\begin{array}{l}0.57^{\mathrm{aB}} \\
(0.04)\end{array}$ & $\begin{array}{c}0.49^{\mathrm{aAB}} \\
(0.01)\end{array}$ \\
\hline Protein* $(\%)$ & $\begin{array}{c}16.54^{\mathrm{dA}} \\
(0.23)\end{array}$ & $\begin{array}{c}16.54^{\mathrm{aA}} \\
(0.23)\end{array}$ & $\begin{array}{c}15.57^{\mathrm{bA}} \\
(0.13)\end{array}$ & $\begin{array}{c}15.70^{\mathrm{cA}} \\
(0.15)\end{array}$ & $\begin{array}{c}15.35^{\mathrm{bA}} \\
(0.09)\end{array}$ & $\begin{array}{c}15.40^{\mathrm{bcA}} \\
(0.15)\end{array}$ & $\begin{array}{c}14.80^{\mathrm{aAB}} \\
(0.15)\end{array}$ & $\begin{array}{c}14.96^{\mathrm{abAB}} \\
(0.13)\end{array}$ & $\begin{array}{c}14.45^{\mathrm{aA}} \\
(0.16)\end{array}$ & $\begin{array}{c}14.52^{\mathrm{aA}} \\
(0.13)\end{array}$ \\
\hline Fat* $(\%)$ & $\begin{array}{l}7.36^{\mathrm{eB}} \\
(0.22)\end{array}$ & $\begin{array}{l}7.31^{\mathrm{dB}} \\
(0.22)\end{array}$ & $\begin{array}{c}6.36^{\mathrm{cAB}} \\
(0.19)\end{array}$ & $\begin{array}{l}6.71^{\mathrm{dB}} \\
(0.18)\end{array}$ & $\begin{array}{l}5.46^{\mathrm{bA}} \\
(0.16)\end{array}$ & $\begin{array}{l}5.62^{\mathrm{cB}} \\
(0.18)\end{array}$ & $\begin{array}{l}4.81^{\mathrm{aA}} \\
(0.14)\end{array}$ & $\begin{array}{l}4.97^{\mathrm{bA}} \\
(0.11)\end{array}$ & $\begin{array}{l}4.57^{\mathrm{aA}} \\
(0.15)\end{array}$ & $\begin{array}{l}4.45^{\mathrm{aA}} \\
(0.15)\end{array}$ \\
\hline
\end{tabular}

Mean values bearing different superscripts in small letters $(a, b, c$ etc) in the columns are significantly different(p<0.05) with respect to sampling days and the values with different superscripts in Caps $(\mathrm{A}, \mathrm{B}, \mathrm{C}$ etc) in the rows are significantly different $(\mathrm{p}<0.05)$ with respect to the treatments.

Table.4 Changes of biochemical parameters during ice storage of FWP and FDP [Values are Mean with the S.E. in parentheses, n=3]

\begin{tabular}{|c|c|c|c|c|c|c|c|c|c|c|}
\hline \multirow[t]{2}{*}{ Parameters } & \multicolumn{2}{|c|}{0 day } & \multicolumn{2}{|c|}{$2^{\text {nd }}$ day } & \multicolumn{2}{|c|}{$4^{\text {th }}$ day } & \multicolumn{2}{|c|}{$6^{\text {th }}$ day } & \multicolumn{2}{|c|}{$8^{\text {th }}$ day } \\
\hline & FWP & FDP & FWP & FDP & FWP & FDP & FWP & FDP & FWP & FDP \\
\hline pH* & $\begin{array}{l}6.36^{\mathrm{aA}} \\
(0.04)\end{array}$ & $\begin{array}{l}6.36^{\mathrm{aA}} \\
(0.04)\end{array}$ & $\begin{array}{c}6.47^{\mathrm{bAB}} \\
(0.02)\end{array}$ & $\begin{array}{c}6.41^{\mathrm{abA}} \\
(0.03)\end{array}$ & $\begin{array}{c}6.52^{\mathrm{bcA}} \\
(0.02)\end{array}$ & $\begin{array}{l}6.49^{\mathrm{bA}} \\
(0.02)\end{array}$ & $\begin{array}{l}6.60^{\mathrm{cA}} \\
(0.05)\end{array}$ & $\begin{array}{c}6.57^{\mathrm{c}} \mathrm{A} \\
(0.01)\end{array}$ & $\begin{array}{l}6.72^{\mathrm{dA}} \\
(0.05)\end{array}$ & $\begin{array}{l}6.76^{\mathrm{dA}} \\
(0.03)\end{array}$ \\
\hline PV* (meq/kg fat) & $\begin{array}{c}11.99^{\mathrm{aA}} \\
(0.29)\end{array}$ & $\begin{array}{c}11.99^{\mathrm{aA}} \\
(0.29)\end{array}$ & $\begin{array}{c}13.51^{\mathrm{bB}} \\
(0.21)\end{array}$ & $\begin{array}{c}13.12^{\mathrm{aAB}} \\
(0.34)\end{array}$ & $\begin{array}{c}15.65^{\mathrm{cA}} \\
(0.14)\end{array}$ & $\begin{array}{c}14.85^{\mathrm{bA}} \\
(0.26)\end{array}$ & $\begin{array}{c}19.16^{\mathrm{dB}} \\
(0.29)\end{array}$ & $\begin{array}{c}18.18^{\mathrm{cB}} \\
(0.33)\end{array}$ & $\begin{array}{c}23.60^{\mathrm{eA}} \\
(0.68)\end{array}$ & $\begin{array}{c}21.97^{\mathrm{dA}} \\
(0.76)\end{array}$ \\
\hline TVBN* (mg \%) & $\begin{array}{l}9.36^{\mathrm{aA}} \\
(0.42)\end{array}$ & $\begin{array}{l}9.36^{\mathrm{aA}} \\
(0.42)\end{array}$ & $\begin{array}{c}11.99^{\mathrm{bA}} \\
(0.67)\end{array}$ & $\begin{array}{c}10.27^{\mathrm{aA}} \\
(0.53)\end{array}$ & $\begin{array}{c}15.30^{\mathrm{cA}} \\
(0.47)\end{array}$ & $\begin{array}{c}14.93^{\mathrm{bA}} \\
(0.39)\end{array}$ & $\begin{array}{c}22.43^{\mathrm{dAB}} \\
(0.63)\end{array}$ & $\begin{array}{c}21.47^{\mathrm{cAB}} \\
(0.63)\end{array}$ & $\begin{array}{c}27.48^{\mathrm{eB}} \\
(0.63)\end{array}$ & $\begin{array}{c}25.25^{\mathrm{dAB}} \\
(0.94)\end{array}$ \\
\hline AAN & $\begin{array}{c}61.69^{\mathrm{aA}} \\
(3.34)\end{array}$ & $\begin{array}{c}61.69^{\mathrm{aA}} \\
(3.34)\end{array}$ & $\begin{array}{c}68.53^{\mathrm{bA}} \\
(4.70)\end{array}$ & $\begin{array}{c}64.48^{\mathrm{aA}} \\
(5.11)\end{array}$ & $\begin{array}{c}73.37^{\mathrm{bA}} \\
(3.97)\end{array}$ & $\begin{array}{c}70.18 b^{\mathrm{AB}} \\
(3.56)\end{array}$ & $\begin{array}{c}79.62^{\mathrm{cAB}} \\
(3.24)\end{array}$ & $\begin{array}{c}81.05^{\mathrm{cA}} \\
(4.40)\end{array}$ & $\begin{array}{c}96.65^{\mathrm{dA}} \\
(4.52)\end{array}$ & $\begin{array}{c}85.95^{\mathrm{cA}} \\
(2.12)\end{array}$ \\
\hline FFA $^{*}$ (\% oleic acid $)$ & $\begin{array}{l}6.14^{\mathrm{aA}} \\
(0.14)\end{array}$ & $\begin{array}{l}6.14^{\mathrm{aA}} \\
(0.14)\end{array}$ & $\begin{array}{c}7.69^{\mathrm{abB}} \\
(0.44)\end{array}$ & $\begin{array}{l}6.72^{\mathrm{aA}} \\
(0.21)\end{array}$ & $\begin{array}{c}9.35^{\mathrm{bcA}} \\
(0.40)\end{array}$ & $\begin{array}{l}9.00^{\mathrm{bA}} \\
(0.38)\end{array}$ & $\begin{array}{c}11.05^{\mathrm{cdA}} \\
(0.97)\end{array}$ & $\begin{array}{c}9.79^{\mathrm{bcA}} \\
(0.81)\end{array}$ & $\begin{array}{c}12.15^{\mathrm{dA}} \\
(1.29)\end{array}$ & $\begin{array}{c}10.68^{\mathrm{cA}} \\
(0.82)\end{array}$ \\
\hline $\begin{array}{l}\text { TBA*(mgmalonaldehyde } \\
\text { /kg }\end{array}$ & $\begin{array}{l}0.65^{\mathrm{aA}} \\
(0.13)\end{array}$ & $\begin{array}{l}0.65^{\mathrm{aA}} \\
(0.13)\end{array}$ & $\begin{array}{l}1.03^{\mathrm{bA}} \\
(0.14)\end{array}$ & $\begin{array}{l}0.76^{\mathrm{aA}} \\
(0.17)\end{array}$ & $\begin{array}{l}0.98^{\mathrm{bA}} \\
(0.03)\end{array}$ & $\begin{array}{l}0.84^{\mathrm{abA}} \\
(0.10)\end{array}$ & $\begin{array}{l}1.16^{\mathrm{bA}} \\
(0.03)\end{array}$ & $\begin{array}{l}1.14^{\mathrm{ccA}} \\
(0.03)\end{array}$ & $\begin{array}{l}1.58^{\mathrm{cAB}} \\
(0.06)\end{array}$ & $\begin{array}{l}1.39^{\mathrm{cA}} \\
(0.07)\end{array}$ \\
\hline
\end{tabular}


Table.5 Change in TPC $(\log 10$ CFU g-1) during ice storage WWP, WDP and FWP, FDP [Values are Mean with the S.E. in parentheses, $n=3$ ]

\begin{tabular}{|c|c|c|c|c|}
\hline Sampling days & WWP & WDP & FWP & FDP \\
\hline $\mathbf{0}$ & $\begin{array}{l}5.04^{\mathrm{aB}} \\
(0.37)\end{array}$ & $\begin{array}{l}5.04^{\mathrm{aB}} \\
(0.37)\end{array}$ & $\begin{array}{l}3.88^{\mathrm{aA}} \\
(0.05)\end{array}$ & $\begin{array}{l}3.88^{\mathrm{aA}} \\
(0.05)\end{array}$ \\
\hline 2 & $\begin{array}{c}5.72^{\mathrm{abA}} \\
(0.25)\end{array}$ & $\begin{array}{c}5.71^{\mathrm{abA}} \\
(0.25)\end{array}$ & $\begin{array}{l}5.39^{\mathrm{bA}} \\
(0.12)\end{array}$ & $\begin{array}{c}5.30^{4 b A} \\
(0.12)\end{array}$ \\
\hline 4 & $\begin{array}{c}6.15^{\mathrm{bcA}} \\
(0.19)\end{array}$ & $\begin{array}{c}6.09^{\mathrm{bcA}} \\
(0.19)\end{array}$ & $\begin{array}{l}5.82^{\mathrm{cA}} \\
(0.04)\end{array}$ & $\begin{array}{l}5.80^{\mathrm{cA}} \\
(0.04)\end{array}$ \\
\hline 6 & $\begin{array}{l}6.65^{\mathrm{cA}} \\
(0.29)\end{array}$ & $\begin{array}{l}6.74^{\mathrm{cA}} \\
(0.27)\end{array}$ & $\begin{array}{l}6.57^{\mathrm{dA}} \\
(0.16)\end{array}$ & $\begin{array}{l}6.49^{\mathrm{dA}} \\
(0.20)\end{array}$ \\
\hline 8 & $\begin{array}{l}7.49^{\mathrm{dA}} \\
(0.15)\end{array}$ & $\begin{array}{l}6.84^{\mathrm{cA}} \\
(0.15)\end{array}$ & $\begin{array}{l}7.31^{\mathrm{dA}} \\
(0.17)\end{array}$ & $\begin{array}{l}6.75^{\mathrm{eA}} \\
(0.15)\end{array}$ \\
\hline
\end{tabular}

Mean values bearing different superscripts in small letters $(a, b$, c etc) in the rows are significantly different $(\mathbf{p}<0.05)$ with respect to sampling days and the values with different superscripts in Caps $(A, B, C$ etc) in the columns are significantly different $(\mathbf{p}<0.05)$ with respect to the treatments

Table.6 Change in psychrophilic count (log10 CFU g-1) during ice storage WWP, WDP and FWP, FDP [Values are Mean with the S.E. in parentheses, $n=3]$

\begin{tabular}{|c|c|c|c|c|}
\hline Sampling days & WWP & WDP & FWP & FDP \\
\hline $\mathbf{0}$ & $5.45^{\mathrm{aA}}$ & $5.45^{\mathrm{aA}}$ & $5.23^{\mathrm{aA}}$ & $5.23^{\mathrm{aA}}$ \\
& $(0.16)$ & $(0.16)$ & $(0.17)$ & $(0.17)$ \\
\hline $\mathbf{2}$ & $5.73^{\mathrm{aB}}$ & $5.89^{\mathrm{bB}}$ & $5.37^{\mathrm{aA}}$ & $5.36^{\mathrm{aA}}$ \\
\hline & $(0.14)$ & $(0.10)$ & $(0.07)$ & $(0.07)$ \\
\hline $\mathbf{4}$ & $6.27^{\mathrm{bA}}$ & $6.33^{\mathrm{cA}}$ & $6.42^{\mathrm{bA}}$ & $6.35^{\mathrm{bA}}$ \\
& $(0.16)$ & $(0.13)$ & $(0.12)$ & 0.12 \\
\hline $\mathbf{6}$ & $6.82^{\mathrm{cA}}$ & $6.74^{\mathrm{dA}}$ & $6.81^{\mathrm{cA}}$ & $6.74^{\mathrm{cA}}$ \\
& $(0.03)$ & $(0.04)$ & $(0.03)$ & $(0.04)$ \\
\hline $\mathbf{8}$ & $7.39^{\mathrm{dA}}$ & $6.91^{\mathrm{eA}}$ & $7.44^{\mathrm{dA}}$ & $6.89^{\mathrm{cA}}$ \\
& $(0.15)$ & $(0.14)$ & $(0.13)$ & $(0.12)$ \\
\hline
\end{tabular}

Mean values bearing different superscripts in small letters $(a, b, c$ etc) in the rows are significantly different $(\mathbf{p}<0.05)$ with respect to sampling days and the values with different superscripts in Capital $(A, B, C$ etc) in the columns are significantly different $(p<0.05)$ with respect to the treatments 
Fig.1a\&b Transversely cut muscle cells of fresh pabda, myofibril was showing closely packed \& Early sign of muscle degradation after the 2nd days of storage
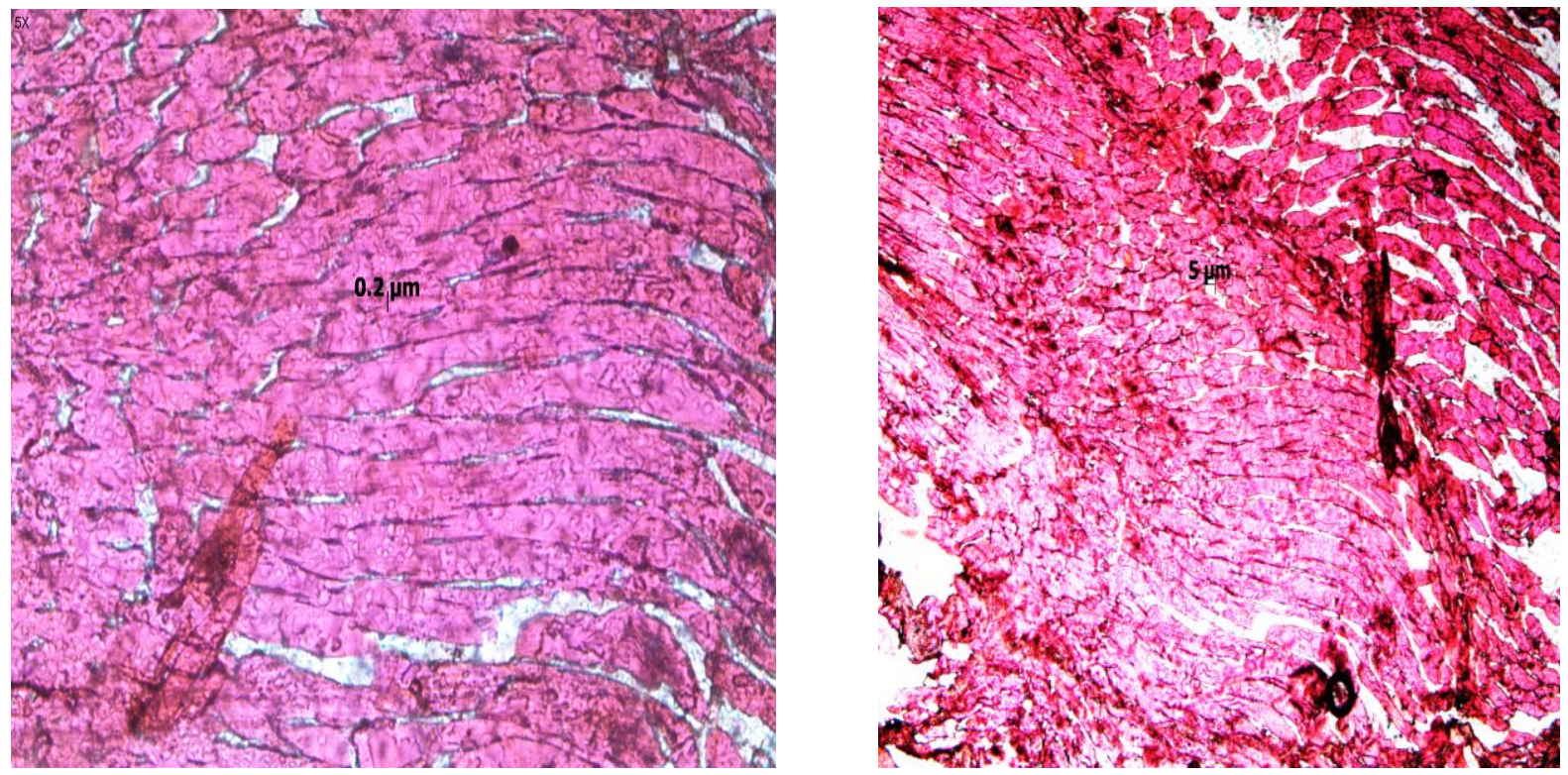

Fig.1c\&d Partial and minor change in microstructure after 4th days of storage \& After the 6th days of storage gapping in the muscle bundles
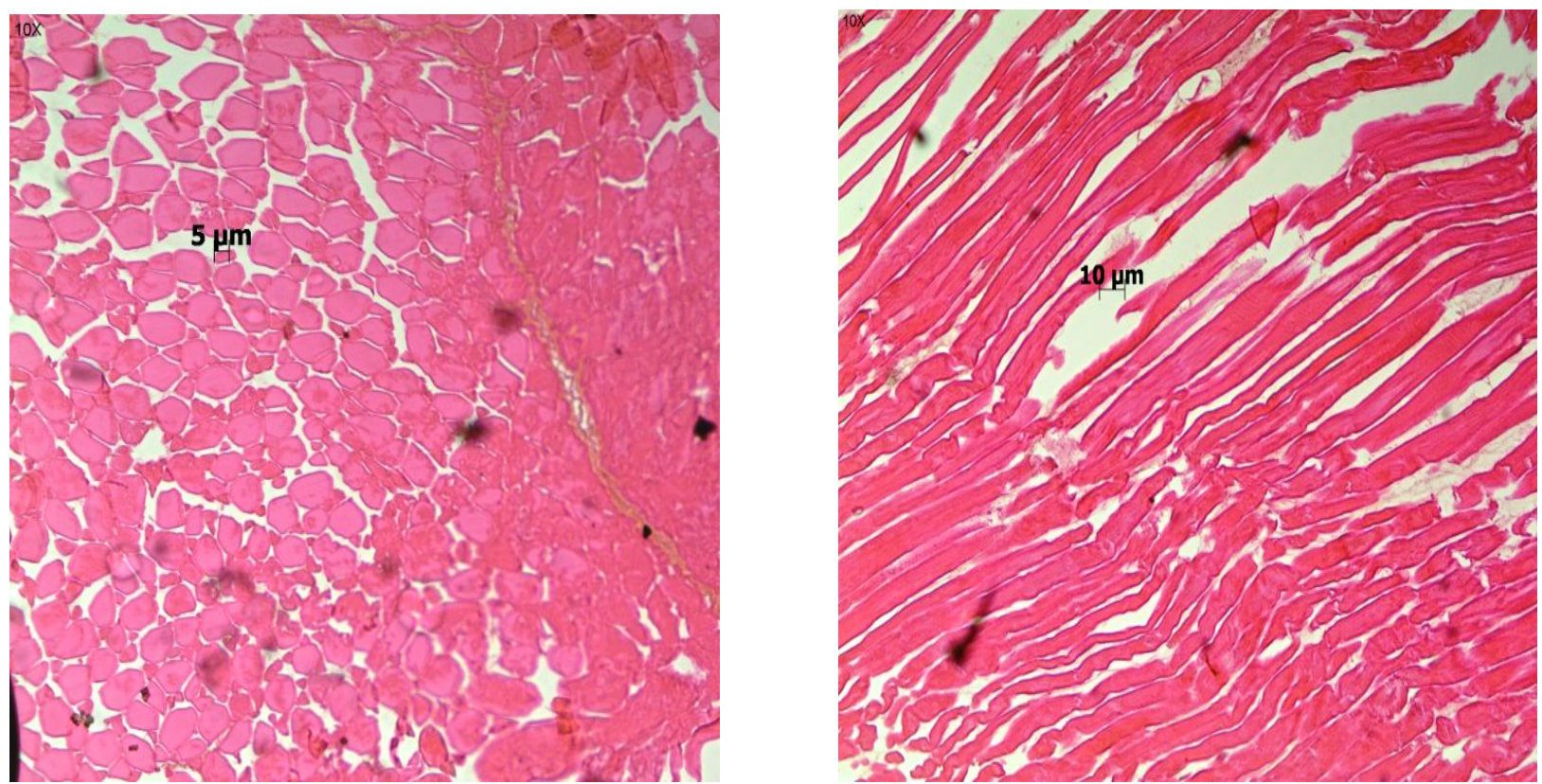
Fig.1e After the 8th days storage destructive changes in cells muscle and dislocation of muscle cells

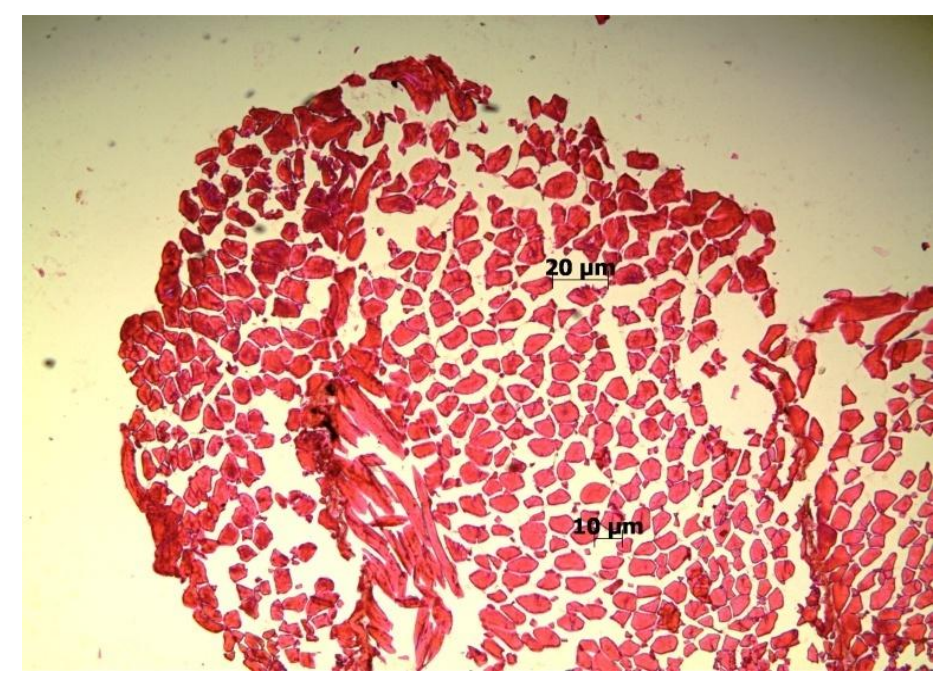

That means the acceptable shelf life of ice stored fish was approximately 6 days as whole and 8 day as the dressed according the TPC parameter. The total psychrophilic count showed significant differences $(\mathrm{p}<0.05)$ in all the treatments during the storage period. It was observed that the initial load of TPC was $5.45 \log \mathrm{cfu} \mathrm{g}^{-1}$ which approached to 7.39 in the WWP and 6.91 in WDP (Table 6). Whereas, in farmed pabda the initial load was observed as 5.23 which increased to 7.44 in FWP and 6.89 in the FDP. However, based on the microbiological acceptability limit (7 log $\mathrm{cfu} \mathrm{g}^{-1}$ ) for fresh and marine species (ICMSF, 2002), the total psychrophilic count exceeded the above the acceptable limit in wild whole and farmed whole pabda. Oppositely, in wild dressed and farmed dressed pabda, the total count did not exceed the acceptable limit. However, it went near to the acceptable limit. The present findings agree with the findings of Bordoloi and Muzaddai (2013) in chilled Labeo rohita.

\section{The changes in muscle structure}

The changes in muscle structure as recorded by histological study are shown in Fig.1A to 1E. The muscle fibres were intact and showing no gaping in the fresh fish (Fig. 1E), whereas there were visible gaping in between the fibres after 6 days of storage (Fig. 1D). The muscle structure was totally dislocated and worn out after 8 days of storage (Fig. 1E).

Fish muscle texture depends on a number of intrinsic biological factors that are related to muscle fibre density, and involving both fat and collagen content (Hernandez et al., 2009). The fish death triggers autolytic and microbiological processes that make the muscle softer and less elastic (Olafsdottir et al., 2004). In the same line of the present findings, earlier study by Menon and Nair (1988) showed the textural changes in iced Labeo calbasu. They found that the early signs of disorganization of the muscle structure were. Characterized by a loss of compactness of the fibers after seven days. Similar results have been reported for few marine fish species (Paleologos et al., 2004; Poli et al., 2006; Taliadourou et al., 2003).

Based on the above finding it can be can conclude that the Biochemical parameters did not show significant differences during storage of whole farmed pabda and whole wild pabda under similar storage condition. 
However, the dressed farmed pabda and dressed wild pabda showed significant improvement in storage shelf life compared to whole pabda. The dressed fish, whether wild or farm, remain acceptable till 6 days when stored in ice. The whole fish remained acceptable up to 3 days only. Thus, present study suggests a method of pabda preservation by minimum dressing and subsequent icing at 1:1 ratio in standard icebox which may be economically useful for the fish retailers.

\section{Acknowledgement}

The authors are grateful to The Dean, College of Fisheries, Central agricultural university, Lembucherra for providing support and infrastructural facilities for carrying out the research.

\section{References}

AOAC, 2000 Official Methods of Analysis, Association of Official Analytical Chemists, AOAC, Vol. I, 16th Edition, sec 942.05. Arlington, Virginia, USA.

Beatty SA, and Gibbons NE. (1937) The measurement of Spoilage of fish. J Biol. Bd Can. 77-91.

Binsi, P. K., Viji, P., Visnuvinayagam, S., Ninan, G., Sangeeta, G., Triveni, A., and Ravishankar, C.N. (2013) Microbiological and shelf life characteristics of eviscerated and vacuum packed freshwater catfish (Ompok pabda) during chill storage. J. Food Sci. Techno. 52:3 1424-1433.

Bloch, M.E. (1794) Ichthyologique, ouhistorienaturcllegenerade particuliere des poisons, part 2, Berlin, pp. 1-142.

Bordoloi, R. and Muzddai, A.U. (2013) Microbiological quality of rohu marketed at Agartala (Tripura) and its public health significance. J. Aqu. food Prod. Techn. 22: 1-12.
Botta, J., Downey, A., Lauder, J., and Neill, O. M. (1982) Chemical and sensory assessment of roundnose grenadier (Macrouru srupestris) subjected to long term frozen storage. J. Food Sci., 47: $1670-1674$

Chakrabarti, R. (2002) Storage characteristics and histamine content of fish stored at tropical ambient temperature. Fish. Techn., 39(1): 34-38

Chytiri, S., Chouliara, I., Savvaidis, I. N. and Kontominas. M. G., (2000) Microbiology, chemical and sensory assessment of iced whole and filleted aquaculture rainbow trout. Food Micro. 21(2):157-165

Conway, E.J., 1947) Microdiffusion analysis and volumetric error. 4th edition. Van Nostrad Co. Inc., New York.

Dyer WJ, Morton ML. (1956) Storage of frozen filter. J Fish. Res. Ed. Can.; 13(1):129-134.

FAO (2018) fisheries and aquaculture department food and agriculture organization of the United Nations Rome,

FAO, (1986) FAO Food and Nutrition paper manuals of food quality control food analysis: quality, adulteration and tests of identity. Food and Agriculture Organization of the United Nations, Rome, Italy.

Fatima, R., Khan, M.A. and Qadri, R.B., (1988). Shelf-life of shrimp Penaeus merguiensis stored in ice and partially frozen $\left(3^{\circ} \mathrm{C}\right)$. J. Sci. Food Agri., 42: 235-247.

Gopakumar K (1997) Biochemical composition of Indian food fish. Central Institute of Fisheries Technology.

Hernández, M.D., López M.B. A., Álvarez, A., Ferrandini E., García B., and Garrido, M.D. (2009) Sensory, physical, chemical and microbiological changes in aquacultured meagre (Argyrosomus regius) fillets during ice storage. Food 
Chem., 114:237-245

Huss, H. H., (1995) Quality and quality changes in fresh fish. FAO Fisheries Technical Paper 348.

ICMSF., (2002) Microorganisms in Foods. Microbiological Testing in Food Safety Management, International Commission on Microbiological Specifications for Foods, Kluwer Academic/Plenum Publishers, Springer, London.

Jacob, M. B., 1958. The Chemical Analysis of Foods and Food Products. pp 393-394. New York, USA, Kreiger Publishing Co. Inc.

Karacam, H. and Boran, M., (1996) Quality change in frozen whole and gutted anchovies during storage at $-18^{\circ} \mathrm{C}$. Int . J. Food Sci. Techno., 31: 527-531

Koizumi, C., Ohshima, T. and Wada, S., (1990) A comparison of the deterioration in quality of freeze dried flesh of halibut (Hippoglossus stenolepis). J. Sci. Food Agri. 52(4): 561-572.

Lokuruka, M. N. I., Muyela, B.,Okeyo, G. O., Shitandi, A. and Otieno, M., (2012) Effect of gutting on sensory, some biochemical and microbiological properties of nile perch (Lates niloticus) and nile tilapia (Oreochromis niloticus) stored in ice. Cont. J. Fish. Aqua. Sci., 6 (3): $1-13$.

Menon, A.V. Girija, and Balakrishnan, Nair, R.,(1988) Histological changes in fresh water fish muscle stored in chilled condition. J. Food Sci. Techn., 25:3, 167-169.

Nazeer RA, Kumar NSS, Naqash SY, Radhika R, Kishore R, and Bhatt SR. (2009). Lipid profiles of threadfin bream(Nemipterus japonicus) organs. Indian J. Marine Sc. 38(4):461-463.

Olafsdottir, G., Nesvadba, P., Di Natale, C., Careche, M., Oehlenschlager, J., and Tryggvadottir, S. V., (2004) Multisensors for fish quality determination. Trends Food Sci. Techn., 15:86-93.

Ozyurt, G., Kuley, E., Ozkutuk, S. and Ozogul, F. (2009) Sensory, microbiological and chemical assessment of the freshness of red mullet (Mullus barbatus) and goldband goatfish (Upeneus moluccensis) during storage in ice. Food Chem., 114(2), 505-510

P, Tanuja S, George N, Zynudheen AA, Lalitha KV. (2014) Quality characteristic and shelf life of sutchi cat fish (Pangasianodon hypophthalamus) steaks during refrigerated storage. International J. Agri. Food Sci. and Techno. 5(2):105-116.

Paleologos, E. K., Savvaidis, I. N., and Kontominas, M., (2004) Biogenic amines formation and its relation to microbiological and sensory attributes in ice- stored whole, gutted and filleted Mediterranean Sea bass (D. labrax). Food Micro.21:549-557.

Poli, B. M., Messini, A., Parisi, G., Scappini, F., Vigiani, V., and Giorgi, G., (2006) Sensory, physical, chemical and microbiological changes in European sea bass (D. labrax) fillets packed under modified atmosphere/air or prepared from whole fish stored in ice. Int. J. Food Sci. Techn., 41:444-454.

Pope, C.G. and Stevans, M.F. (1939) Biochem. J. 33:1070.

Roopma, Gandothra, Shalini S. (2012) Effect of chilling and freezing on fish muscle. IOSR J. Pharm. Biolo. Sci. 2(5): 22783008.

Sikorski. Z. E. and Kolakowska A., (1994) Changes in protein in frozen stored fish. In Sikorski. Z., Sun Pan. B., Shahidi, F. (Ed), Seafood Proteins. New York, USA, Chapman and Hall. pp. 99-112.

Taliadourou, D., Papadopoulos, V., Domvridou, E., Savvaidis, I. N., and Kontominas, K. G.

(2003) 
Microbiological, chemical and sensory changes of whole and filleted 98 Mediterranean aquacultured sea bass (D. labrax) stored in ice. J. Sci. Food and Agri., 83:1373-1379.

Tarladgis, B. G., Watts, B. M. and Younathen, M. T., (1960) A distillation method for quantitative determination of malonaldehyde in rancid foods. J. American Oil Chem. Soci., 37:44-48.

Tokur B, Ozkutuk S, Atici E, Ozyurt G, Ozyurt CE. (2006) Chemical and sensory quality changes of fish fingers, made from mirror carp (Cyprinus carpio L, 1758), during frozen storage $\left(-18^{\circ} \mathrm{C}\right)$. Food Chem.; 99(2):335-341.

Viji P., Tanuja S., George Ninan.,Zynudheen A.A, and Lalitha, K.V. (2014) Quality Characteristics and Shelf Life of Sutchi Cat Fish (Pangasianodon hypophthalmus) Steaks During Refrigerated Storage. Int. J. Agri. Food Sci. Techn. 5:2-105-116

\section{How to cite this article:}

Jag Pal, A.U. Muzaddadi and Hemant Hari Tripathi. 2019. Biochemical and Histological Change during Chilled Storage in Farmed Raised and Wild Indian Butter Catfish (Ompok bimaculatus Bloch, 1794). Int.J.Curr.Microbiol.App.Sci. 8(03): 1410-1422.

doi: https://doi.org/10.20546/ijcmas.2019.803.165 